ФІЗИЧНЕ ВИХОВАННЯ РІЗНИХ ГРУП НАСЕЛЕННЯ

\title{
THE INFLUENCE OF INDEPENDENT CLASSES IN PHYSICAL EDUCATION ON THE PHYSICAL FITNESS OF SENIOR SCHOOLCHILDREN
}

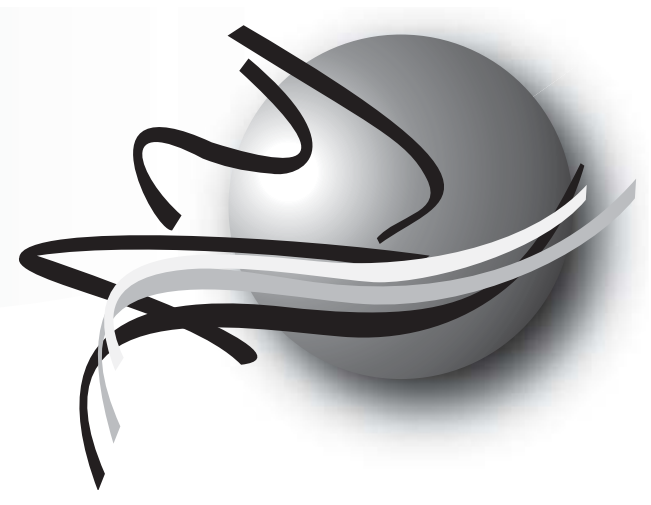

\author{
Moskalenko Natalia, Demidova Oksana, Yelisieieva Daria \\ Pridneprovsk State Academy of Physical Culture and Sport
}

DOI: 10.32540/2071-1476-2019-1-323

\section{Annotation}

Introduction. The development of Ukraine cannot be achieved without the powerful educational potential of the nation, namely, not high-quality training of specialists in all sectors. The realization of this goal is impossible without one of the most important components of the educational process - physical education. Physical education helps students in the formation of professional skills, brings up the basics of a healthy lifestyle, improves their health, and increases the level of physical and functional fitness. Therefore, the issues of improving the content, forms and methods of physical education of schoolchildren in secondary schools remain relevant. The article considers and analyzes the importance of independent physical education classes. An innovative technology is proposed to increase the interest of schoolchildren in independent physical education classes with the aim of increasing physical fitness indicators, as well as maintaining and strengthening health.

Hypothesis of the study is that independent physical education will improve the physical fitness of high school students.

Research purpose to determine the impact of different types of independent physical education on the physical fitness of high school students.

Research methods and materials. The proposed innovative technology contains the following components: purpose, objectives, directions, organizational and pedagogical conditions, stages of implementation and performance criteria, which in turn are related to each other and in the complex solve the problem of involving high school students in independent physical education. Methods: analysis and theoretical generalization of scientific and methodological literature, pedagogical observation, pedagogical experiment, pedagogical testing, methods of mathematical statistics. The study involved 74 high school seniors who belong to a major medical group and have no health disabilities.

Results. The data of the experimental study of the impact of the developed innovative technology on the indicators of physical fitness of older school-age children are presented and its effectiveness is proved.

Conclusions. In order to improve the performance of older school-age students, innovative technology was proposed that included the use of information technology and control systems. After the introduction of innovative technology, qualitative characteristics of physical fitness showed that the majority of students EG1, EG2, EG3 and EG4 after the experiment have a sufficient level of physical fitness $(p<0,05)$.

Keywords: innovative technology, health, high school students, self-study, physical education.

\section{Анотація}

Вступ. Розвиток України неможливо здійснити без потужного освітнього потенціалу нації, а саме, - без якісної підготовки фахівців у всіх галузях. Реалізація цієї мети неможлива без однієї з найважливіших складових освітнього процесу - фізичного виховання. Фізичне виховання допомагає школярам при формуванні професійних навичок, виховує основи здорового способу життя, дозволяє покращити їх здоров'я, підвищити

(C) Moskalenko N., Demidova O.,

Yelisieieva D., 2020 
рівень фізичної та функціональної підготовленості. Тому актуальними залишаються питання вдосконалення змісту, форм і методів фізичного виховання школярів у загальноосвітніх закладах. У статті розглянуто і проаналізовано значення самостійних занять фізичним вихованням. Запропоновано інноваційну технологію підвищення інтересу школярів до самостійних занять фізичним вихованням з метою підвищення показників фізичної підготовленості, а також збереження і зміцнення здоров'я.

Гіпотеза дослідження полягає у тому, що самостійні заняття фізичним вихованням дозволять покращити показники фізичної підготовленості старшокласників.

Мета дослідження: визначити вплив різних видів самостійних занять фізичним вихованням на фізичну підготовленість старшокласників.

Матеріал і методи дослідження. Запропонована інноваційна технологія містить складові: мету, завдання, спрямованості, організаційно-педагогічні умови, етапи впровадження та критерії ефективності, які в свою чергу пов'язані між собою та у комплексі вирішують завдання залучення старшокласників до самостійних занять фізичним вихованням. Методи: аналіз і теоретичне узагальнення науково-методичної літератури, педагогічне спостереження, педагогічний експеримент, педагогічне тестування, методи математичної статистики. У дослідженні взяли участь 74 старшокласника, які належать до основної медичної групи і не мають відхилень у стані здоров'я.

Результати. Представлено дані експериментального дослідження впливу розробленої інноваційної технології на показники фізичної підготовленості учнів старшого шкільного віку та доведено їі ефективність.

Висновки. 3 метою підвищення показників фізичної підготовленості учнів старшого шкільного віку було запропоновано інноваційну технологію яка включала використання інформаційно-технічних засобів і системи контролю. Після впровадження інноваційної технології якісна характеристика фізичної підготовленості показала, що більшість школярів ЕГ1, ЕГ2, ЕГ3 та ЕГ4 після експерименту мають достатній рівень фізичної підготовленості $(\mathrm{p}<0,05)$.

Ключові слова: інноваційна технологія, здоров'я, старшокласники, самостійні заняття, фізичне виховання.

\section{Аннотация}

Вступление. Развитие Украины невозможно осуществить без мощного образовательного потенциала нации, а именно, - не качественной подготовки специалистов во всех отраслях. Реализация этой цели невозможна без одной из важнейших составляющих образовательного процесса - физического воспитания. Физическое воспитание помогает школьникам при формировании профессиональных навыков, воспитывает основы здорового образа жизни, позволяет улучшить их здоровье, повысить уровень физической и функциональной подготовленности. Поэтому актуальными остаются вопросы совершенствования содержания, форм и методов физического воспитания школьников в общеобразовательных учреждениях. В статье рассмотрены и проанализированы значение самостоятельных занятий физическим воспитанием. Предложено инновационную технологию повышения интереса школьников к самостоятельным занятиям физическим воспитанием с целью повышения показателей физической подготовленности, а также сохранения и укрепления здоровья.

Гипотеза исследования заключается в том, что самостоятельные занятия физическим воспитанием позволят улучшить показатели физической подготовленности старшеклассников.

Цель исследования: определить влияние различных видов самостоятельных занятий физическим воспитанием на физическую подготовленность старшеклассников.

Материал и методы исследования. Предложенная инновационная технология включает следующие составляющие: цели, задачи, направленность, организационно-педагогические условия, этапы внедрения и критерии эффективности, которые в свою очередь связаны между собой и в комплексе решают задачи привлечения старшеклассников к самостоятельным занятиям физическим воспитанием. Методы: анализ и теоретическое обобщение научно-методической литературы, педагогическое наблюдение, педагогический эксперимент, педагогическое тестирование, методы математической статистики. В исследовании приняли участие 74 старшеклассника, принадлежащих к основной медицинской группе и не имеющие отклонений в состоянии здоровья.

Результаты. Представлены данные экспериментального исследования влияния разработанной инновационной технологии на показатели физической подготовленности учащихся старшего школьного возраста и доказана ее эффективность.

Выводы. С целью повышения показателей физической подготовленности учащихся старшего школьного возраста было предложено инновационную технологию которая включала использование информационнотехнических средств и системы контроля. После внедрения инновационной технологии качественная характеристика физической подготовленности показала, что большинство школьников ЕГ1, ЕГ2, ЕГ3 и ЭГ4 после 
эксперимента имеют достаточный уровень физической подготовленности (p <0,05).

Ключевые слова: инновационная технология, здоровье, старшеклассники, самостоятельные занятия, физическое воспитание.

\section{Introduction}

Analysis of the development of modern school education system in Ukraine shows that, despite the avalanche of innovations in the system of education and training, they are of little concern to the field of physical education. The educational process of secondary school is increasingly overloaded with subjects that develop only mental activity, and the decrease in the level of physical development of modern children and the deterioration of their health are not taken into account. At the same time, deviations in school practice from the purpose of physical education and reducing it to a purely normative approach, which has been observed in recent years, not only contradicts the idea of forming a harmoniously developed personality, but also enhances the critical health state of schoolchildren [1, 4, $7,12]$.

The statement of universal values, preservation of health of Ukraine's citizens is extremely actual problem of the present. Now the world community considers the problem of health as that which belongs to the circle of global problems, the solution of which determines the further existence of mankind $[6,13,17]$.

The determining role in solving this problem belongs to the modern system of physical education, which gradually becomes an integral part of the lifestyle and affects the education, upbringing and human health $[2,13]$. Unfortunately, the effectiveness of physical education is at an unsatisfactory level and is not able to meet the interests and needs of the population. Physicians record the deterioration of children's health: $90 \%$ of graduates have certain health disorders, of which: 70 $\%$ - poor vision, $60 \%$ - scoliosis,
$40 \%$ - diseases of the cardiovascular system, $40.5 \%$-diseases of the gastrointestinal tract $[3,9,15]$.

Today it is certain that the main reasons for this situation is the lack of motor activity, which in turn negatively affects physical condition of schoolchildren.

Authors Moskalenko N. Savchenko V. (2018) indicate that compulsory physical education classes at school are not always able to fill the deficit of motor activity of schoolchildren, to ensure the restoration of their mental performance, to prevent diseases developing against the background of chronic fatigue. This task is facilitated by independent classes of physical education [13].

As it is stated [14, 16, 17] independent classes of physical culture and sports help to eliminate the shortcomings of their motor activity, contribute to a more active assimilation of the program and passing the standards. In the process of independent classes provides an opportunity to master new motor skills and abilities that are not presupposed by the curriculum of physical education, to expand the range of motor actions, as well as to improve the physical condition of schoolchildren.

Analyzing the abovementioned, it can be stated that the problem of attracting high school children to systematic independent physical education in order to improve physical fitness is still relevant.

\section{Materials and methods of re-} search

The purpose is to determine the impact of different types of independent physical education classes on the physical fitness of high school children.

The object of the research is the system of physical education of senior schoolchildren.
The subject of the research is the influence of independent physical education classes on the level of physical fitness of senior schoolchildren.

Research methods: analysis and theoretical generalization of scientific and methodical literature, pedagogical observation, pedagogical experiment, pedagogical testing, methods of mathematical statistics.

Statistical analysis. The study results were processed using statistical methods on a personal computer using the STATISTICA 6.0 automated data processing system application software suite and the EXCEL spreadsheet editor for Mac2015. The likelihood of differences was estimated using the MannyWhitney (U) criterion.

Participants. To solve the set tasks, 74 high school students aged 16 to 17 were involved in the pedagogical experiment. Informed consent to participate in this experiment was obtained from all participants.

Organization of research. The research was conducted on the bases of educational complex №28, secondary school №75, Dnipro. The study involved 74 high school seniors who belong to a major medical group and have no health disabilities.

\section{Results}

The modern system of mastering the values of physical culture and sports is based on theoretical concepts that define innovative approaches and new pedagogical technologies that have been formed in the theory of physical culture in recent decades.

The introduction of innovations and implementation of innovative processes in the physical education of senior schoolchildren are becoming fundamentally important today. The basis of innovative processes in 
OBJECTIVE: increase of the health level, the level of motor activity, the formation of motivation of senior schoolchildren to active, systematic independent physical education classes

TASKS: planning of rational organization of sports and recreational activities of high school students in their free time; involving students in regular independent physical education classes; improving the physical condition of the body; the formation of a positive attitude to physical exercise; the formation of sustainable motivational attitudes to maintain and strengthen health; arrangement of schoolchildren's leisure

PRINCIPLES: frequency; access; personalization; consistency; continuity; health orientation; awareness and activeness; the all-round development of a personality; the priority of personal needs

\begin{tabular}{|c|c|c|c|c|c|}
\hline \multicolumn{6}{|c|}{ ORIENTATION OF INDEPENDENT CLASSES } \\
\hline \multicolumn{6}{|c|}{4} \\
\hline Hygienic & $\begin{array}{l}\text { Health and } \\
\text { recreational }\end{array}$ & Therapeutic & $\begin{array}{l}\text { General } \\
\text { physical }\end{array}$ & Sport & $\begin{array}{l}\text { Professional- } \\
\text { applied }\end{array}$ \\
\hline \multicolumn{6}{|c|}{ ORGANIZATIONAL-PEDAGOGICAL CONDITIONS OF THE IMPLEMENTATION } \\
\hline \multicolumn{2}{|c|}{$\begin{array}{l}\text { Development of the system of involving } \\
\text { senior schoolchildren in independent } \\
\text { physical education classes }\end{array}$} & \multicolumn{2}{|c|}{$\begin{array}{c}\text { Formation of a positive attitude of high } \\
\text { school children to independent physical } \\
\text { education classes }\end{array}$} & \multicolumn{2}{|c|}{$\begin{array}{l}\text { Mastering knowledge of } \\
\text { physical culture and } \\
\text { formation of attitudes to } \\
\text { maintain a healthy lifestyle, } \\
\text { learning self-control and } \\
\text { the ability to self- } \\
\text { engagement in physical } \\
\text { exercise }\end{array}$} \\
\hline \multicolumn{6}{|c|}{ IMPLEMENTATION PHASE } \\
\hline \multicolumn{2}{|c|}{$\begin{array}{l}1^{\text {st }} \text { phase } \\
\text { preparatory }\end{array}$} & \multicolumn{2}{|c|}{$\begin{array}{l}2^{\text {nd }} \text { phase } \\
\text { main }\end{array}$} & \multicolumn{2}{|c|}{$\begin{array}{l}3^{\mathrm{d}} \text { phase } \\
\text { final (resultative) }\end{array}$} \\
\hline \multicolumn{6}{|c|}{ EFFECTIVENESS CRITERIA_ } \\
\hline $\begin{array}{c}\text { Formation of } \\
\text { knowledge on a } \\
\text { healthy lifestyle and } \\
\text { instructions for its } \\
\text { implementation }\end{array}$ & $\begin{array}{l}\text { Improving } \\
\text { the indices of } \\
\text { physical health } \\
\text { and physical } \\
\text { fitness }\end{array}$ & $\begin{array}{l}\text { Increase in the volume } \\
\text { of senior } \\
\text { schoolchildren's motor } \\
\text { activity }\end{array}$ & $\begin{array}{r}\text { The preser } \\
\text { motivation an } \\
\text { interest in ind } \\
\text { physical ed } \\
\text { classe }\end{array}$ & $\begin{array}{l}\text { e of } \\
\text { strong } \\
\text { pendent } \\
\text { ation }\end{array}$ & $\begin{array}{l}\text { Ability to plan } \\
\text { independent } \\
\text { physical } \\
\text { education } \\
\text { classes }\end{array}$ \\
\hline
\end{tabular}

Fig. 1. Innovation technology scheme

physical education are the creation and implementation of innovations which contribute to the revitalization of schoolchildren's independent motor activity; mastering by schoolchildren methodology and technology of innovative implementations.

For the effective implementation of the system of involving schoolchildren to independent classes of physical education, the formation of their personal physical culture, improving their health, we have de- veloped an innovative technology, which includes the basic methodological provisions, components and criteria of effectiveness.

The developed innovative technology contains seven main components: the purpose, objectives, principles, orientation of independent classes, organizational and pedagogical conditions, stages of implementation and effectiveness criteria, which are interconnected and in a complex solve the problem of involving high school students to independent physical education classes (fig. 1).

The basis of the developed innovative technology is information and practical approaches to the formation of health and healthy lifestyle of schoolchildren: their familiarization with the variety of traditional and innovative means and methods of preserving and strengthening health, education of their needs in a healthy lifestyle.

(C) Moskalenko N., Demidova O., Yelisieieva D., 2020 


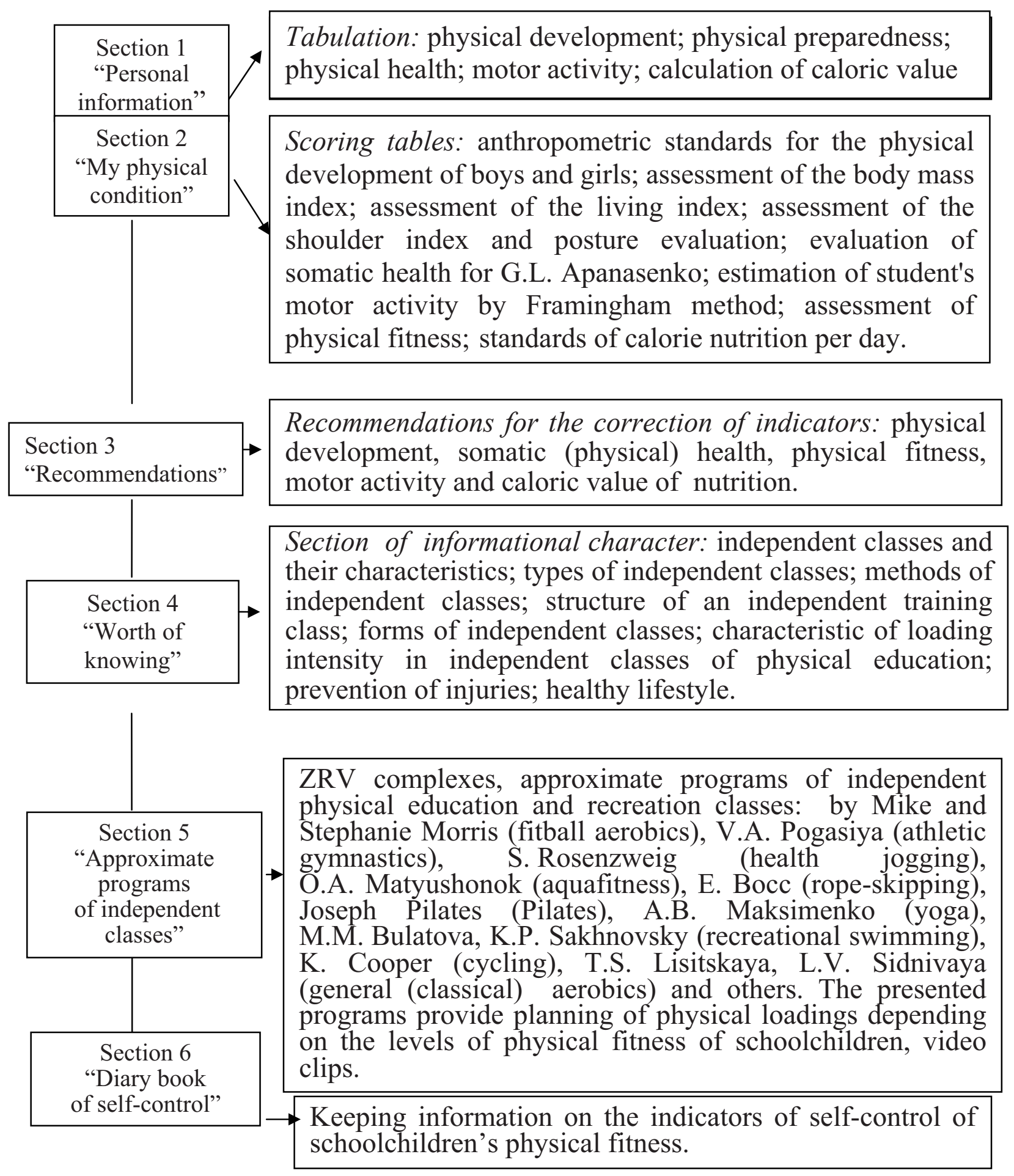

The specifics of working with senior schoolchildren provided for the consideration of their individual characteristics and the search for the most interesting forms of theoretical material for the formation of motivation for independent physical training. Therefore, we have developed a website, the main purpose of which is aimed at: the formation of

(C) Moskalenko N., Demidova O., Yelisieieva D., 2020 interest in independent activity of schoolchildren; maintaining health; maintaining a high level of physical and mental performance. Access mode: heals-diary.herokuapp.com.

The website has an integrated structure and contains 6 sections (Fig. 2), each of these sections has a specific purpose and can be used independently of the others.
Schoolchildren used the resources of the developed website, which allows to choose indicative programs of physical culture and health classes, taking into account individual indicators of physical development, physical fitness, physical activity and health. They made and presented a project of independent physical culture and health 
Table 1

Indicators of physical fitness of female youngsters of studied groups before and after the experiment

\begin{tabular}{|c|c|c|c|c|c|c|}
\hline \multirow[b]{2}{*}{ Phase of the experiment } & \multicolumn{2}{|c|}{ EG $1(n=19)$} & \multirow{3}{*}{$\mathrm{p}$} & \multicolumn{2}{|c|}{ EG $2(n=18)$} & \multirow{3}{*}{$\mathrm{p}$} \\
\hline & before & after & & before & after & \\
\hline Indicators & $\overline{\mathrm{x}} \pm \mathrm{S}$ & $\overline{\mathrm{x}} \pm \mathrm{S}$ & & $\overline{\mathrm{x}} \pm \mathrm{S}$ & $\overline{\mathrm{x}} \pm \mathrm{S}$ & \\
\hline $\begin{array}{l}\text { Bending and straightening } \\
\text { arms in lying support } \\
\text { against a bench, amount }\end{array}$ & $8,3 \pm 0,76$ & $13,1 \pm 1,23$ & $\mathrm{p}<0,05$ & $8,9 \pm 0,99$ & $10,8 \pm 1,71$ & $\mathrm{p}<0,05$ \\
\hline Pulling in hang lying down, amount & $6,2 \pm 1,36$ & $10,9 \pm 1,55$ & $\mathrm{p}<0,05$ & $5,9 \pm 1,23$ & $8,9 \pm 2,80$ & $\mathrm{p}<0,05$ \\
\hline $\begin{array}{l}\text { Lifting the trunk sitting } \\
\text { over } 60 \text { sec., amount }\end{array}$ & $20,8 \pm 2,69$ & $27,0 \pm 1,30$ & $\mathrm{p}<0,05$ & $21,0 \pm 2,00$ & $30,1 \pm 2,76$ & $\mathrm{p}<0,05$ \\
\hline Standing long jump, $\mathrm{cm}$ & $150,8 \pm 2,16$ & $151,2 \pm 3,01$ & $\mathrm{p}>0,05$ & $151,2 \pm 2,21$ & $151,9 \pm 2,87$ & $\mathrm{p}>0,05$ \\
\hline Run 100 metres, $\mathrm{s}$ & $19,1 \pm 2,40$ & $17,4 \pm 2,29$ & $\mathrm{p}<0,05$ & $19,3 \pm 3,44$ & $19,1 \pm 3,76$ & $\mathrm{p}>0,05$ \\
\hline Shuttle run $4 \times 9 \mathrm{~m}, \mathrm{~s}$ & $11,3 \pm 1,67$ & $9,7 \pm 1,98$ & $\mathrm{p}<0,05$ & $11,9 \pm 1,41$ & $9,5 \pm 1,55$ & $\mathrm{p}<0,05$ \\
\hline $\begin{array}{l}\text { Forward trunk bending from } \\
\text { a sitting position, } \mathrm{cm}\end{array}$ & $12,4 \pm 2,40$ & $17,9 \pm 2,18$ & $\mathrm{p}<0,05$ & $10,2 \pm 1,69$ & $15,1 \pm 1,39$ & $\mathrm{p}<0,05$ \\
\hline Uniform running $1500 \mathrm{~m}$, min & $10,9 \pm 2,02$ & $8,8 \pm 2,74$ & $\mathrm{p}<0,05$ & $10,5 \pm 2,00$ & $9,8 \pm 1,21$ & $\mathrm{p}>0,05$ \\
\hline
\end{tabular}

classes selected types of motor activity: basic (classical) aerobics, fitball aerobics, athletic gymnastics, jogging, and engaged in the selected types of physical culture and health programs of independent classes, which included: conducting independent classes 3 times a week, the duration of each health class was 60-70 minutes. At every 15-th independent lesson the automated control testing on indicators of physical development, physical readiness, a state of health which are presented on the website was carried out. According to the physical condition of schoolchildren, adjustments were made regarding the content, volume and intensity of independent studies.

Students wishing to study independently were distributed into four experimental groups (EG1, EG2, EG3 and EG4). The stuff of the first experimental group (EG1) included most of the 16 years old girls' number $(n=19)$, who chose general (classical) aerobics for independent physical education, the second experimental group (EG2) were girls of $17(n=18)$, who chose fitball aerobics for independent classes. The third and the fourth experimental group (EG3, EG4) consisted of male youngsters aged 16 and 17 , most of which $(n=20)$ chose for independent classes artistic gymnastics and $(n=17)$ jogging.

The studied groups of girls EG1, EG2 and boys EG3, EG4 before the experiment had no significant differences on tests: "bending and straightening arms in lying support", "pulling in hang lying down", "lifting the trunk sitting over 60 sec.", "standing long jump", "shuttle run $4 \times 9$ m" "run 100 metres", " forward trunk bending from a sitting position, uniform running $1500 \mathrm{~m}$ ( $>0.05)$. Histograms of the distribution for each case were constructed. The results make it possible to state that the samples are subject to the law of normal distribution.

Analysis of physical fitness of girls showed (table 1) that in EG1 and EG2 after the experiment most of the indicators have statistically significant changes $(\mathrm{p}<0.05)$.

It is possible to notice that independent classes of general (classic) aerobics contribute to the improvement of nearly all physical qualities, and independent classes of fitball aerobics are most conducive to development of such physical qualities as strength, agility and flexibility.

Assessing physical fitness of mail youngsters of EG3 (table. 2), we can conclude that the largest increase of results was in tests "bending and straightening the arms in lying support ", " pulling in hang lying down, " lifting the trunk sitting over $60 \mathrm{sec}$ ", "run $100 \mathrm{~m}$ ", and "standing long jump". It indicates that the system of independent classes of athletic gymnastics has a positive effect on strength and speedstrength physical qualities.

In EG4, the greatest increase in results occurred in the tests " Lifting the trunk sitting over $60 \mathrm{sec} . "$, "standing long jump", "run 100 m", "Shuttle run $4 \times 9 \mathrm{~m}$ ", " forward trunk bending from a sitting position " and "uniform running $1500 \mathrm{~m}$ ". It in turn indicates the improvement of physical qualities such as speed, speedstrength physical qualities, endurance and agility.

\section{Discussion}

The above mentioned states that the selected by senior schoolchildren independent classes of general (classical) aerobics, fitball aerobics, athletic gymnastics and jogging contribute to a significant increase in physical fitness, and therefore, we can talk about the effectiveness of the presented innovative technology. If one compares the impact 
Table 2

Indicators of physical fitness of male youngsters of studied groups before and after the experiment

\begin{tabular}{|c|c|c|c|c|c|c|}
\hline \multirow[b]{2}{*}{ Phase of the experiment } & \multicolumn{2}{|c|}{ EG $3(n=20)$} & \multirow{3}{*}{$\mathrm{p}$} & \multicolumn{2}{|c|}{ EG4 $(n=17)$} & \multirow{3}{*}{$\mathrm{p}$} \\
\hline & before & after & & before & after & \\
\hline Indicators & $\overline{\mathrm{x}} \pm \mathrm{S}$ & $\overline{\mathrm{x}} \pm \mathrm{S}$ & & $\overline{\mathrm{x}} \pm \mathrm{S}$ & $\overline{\mathrm{x}} \pm \mathrm{S}$ & \\
\hline $\begin{array}{l}\text { Bending and straightening } \\
\text { arms in lying support } \\
\text { against a bench, amount }\end{array}$ & $15,1 \pm 1,47$ & $20,2 \pm 1,59$ & $\mathrm{p}<0,05$ & $15,5 \pm 2,00$ & $17,0 \pm 1,32$ & $\mathrm{p}>0,05$ \\
\hline Pulling in hang lying down, amount & $6,5 \pm 1,23$ & $10,1 \pm 1,89$ & $\mathrm{p}<0,05$ & $6,8 \pm 1,70$ & $7,5 \pm 0,99$ & $\mathrm{p}>0,05$ \\
\hline $\begin{array}{l}\text { Lifting the trunk sitting } \\
\text { over } 60 \text { sec., amount }\end{array}$ & $26,6 \pm 2,10$ & $32,1 \pm 1,50$ & $\mathrm{p}<0,05$ & $26,1 \pm 1,72$ & $31,8 \pm 1,91$ & $\mathrm{p}<0,05$ \\
\hline Standing long jump, $\mathrm{cm}$ & $202,5 \pm 1,97$ & $211,1 \pm 2,04$ & $\mathrm{p}<0,05$ & $204,1 \pm 2,75$ & $214,5 \pm 1,90$ & $\mathrm{p}<0,05$ \\
\hline Run 100 metres, $\mathrm{s}$ & $15,9 \pm 1,62$ & $15,1 \pm 1,74$ & $\mathrm{p}<0,05$ & $15,2 \pm 1,30$ & $14,7 \pm 2,03$ & $\mathrm{p}<0,05$ \\
\hline Shuttle run $4 \times 9 \mathrm{~m}, \mathrm{~s}$ & $9,1 \pm 1,99$ & $8,2 \pm 2,80$ & $\mathrm{p}>0,05$ & $9,2 \pm 2,55$ & $8,9 \pm 2,00$ & $\mathrm{p}<0,05$ \\
\hline $\begin{array}{l}\text { Forward trunk bending from } \\
\text { a sitting position, } \mathrm{cm}\end{array}$ & $4,1 \pm 1,20$ & $4,8 \pm 1,33$ & $\mathrm{p}>0,05$ & $3,9 \pm 1,89$ & $4,0 \pm 1,39$ & $\mathrm{p}>0,05$ \\
\hline Uniform running $1500 \mathrm{~m}$, min & $8,9 \pm 2,22$ & $7,0 \pm 2,41$ & $\mathrm{p}>0,05$ & $8,6 \pm 1,99$ & $7,4 \pm 1,60$ & $\mathrm{p}<0,05$ \\
\hline
\end{tabular}

of independent classes of general (classical) aerobics and fitball aerobics on the level of physical fitness of female youngsters in the experimental groups, one can say that the general (classical) aerobics classes were more effective, since most of the statistically significant changes occurred in EG1. Here such physical qualities as strength of muscles of the upper shoulder girdle, dexterity, speed, endurance and flexibility have significantly improved. Besides, most of female youngsters after the experiment showed a sufficient level of competence on almost all tests. In EG2 female youngsters independent fitball aerobics classes had a statistically significant effect only on the strength of the abdominal muscles, agility and flexibility.

Comparing the influence of independent classes of athletic gymnastics and jogging on the physical fitness of male youngsters, it can be stated that independent classes of jogging in EG4 were more effective, because it improved the results of motor tests of such physical qualities as the strength of the muscles of the lower extremities, speed, endurance and agility, in contrast to EG3, where changes occurred only in data of muscles strength of the upper shoulder girdle, as well as abdominal muscles. In addition, most of the male youngsters of EG4 after the experiment had a sufficient level of physical fitness.

\section{Conclusion}

In the purpose to increase indexes of physical fitness of senior schoolchildren were offered the innovative technology that included the use of information technology equipment and control systems. The innovative technology contains the following components: purpose, objectives, orientation, organizational and pedagogical conditions, stages of implementation and efficiency criteria, which in turn are interconnected and in complex solve the problem of involving senior schoolchildren in independent classes of physical education and carry out a comprehensive impact on the conscious, sensory-emotional and active spheres of personality. After the introduction of the innovative technology qualitative characteristics of physical fitness showed that most of the students from EG1, EG2, EG3 and EG4 after the experiment have a sufficient level of physical fitness $(\mathrm{p}<0.05)$.

Acknowledgments. We are grateful to the administration of the educational complex №28, secondary school №75 for the opportunity to conduct research bases at secondary education establishments.

Conflict of interests. The authors declare no conflict of interest.

\section{Література}

1. Абрамов Р., Болотова I. Інноваційні соціальні практики та технології фізичної культури i спорту. Вісник Омського університету. Серія Соціологія. 2018. №1-2. С. 37-62.

2. Боднар I. Р. Теоретико-методичні основи інтегративного фізичного виховання школярів I-III

\section{References}

1. Abramov R., Bolotova I. (2018). Innovative social practices and technologies of physical culture and sports. Herald of Omsk University. Series Sociology. No.1-2. P. 37-62. (in Russian).

2. Bodnar I. R. (2008). Theoretical and methodological foundations of integrative physical education

(C) Moskalenko N., Demidova O.,

Yelisieieva D., 2020 
груп здоров'я [дисертація]. 24.00.02. Львів: Львів. держ. ун-т фіз. культури; 2014. 400 с.

3. Боднар I. Р., Кіндзера А. Б. Дозвілля українських школярів і місце рухової активності у ньому. Педагогіка, психологія та медико-біологічні проблеми фізичного виховання і спорт. 2016. № 5. С.11-18. Дой: 10.15561/18189171. 2016.0502.

4. Демідова О.М. Фізична підготовка танцюристів 15-16 років на етапі спеціалізованої базової підготовки. дисертація на здоб. наук. ступеня кандидата наук з фізичного виховання і спорту 24.00.01 олімпійський і професійний спорт. Дніпропетровськ. ДДІФКіС. 2015. 230 с.

5. Foran A. Physical Activity and Heals Guidelines: Recommendations for Various Ages, Fitness Levels, and Conditions from 57 Authoritative Sources. Paperback. 2010. 368 p.

6. Інноваційні технології у фізичному вихованні школярів. [навч. посібник для студ. вищ. навч. закладів] / Москаленко Н.В., Власюк О.О., Степанова I.В., Шиян О.В. Дніпропетровськ: «Інновація». 2011. 235 с.

7. Москаленко Н.В. Теоретико-методичні засади інноваційних технологій в системі фізичного виховання молодших школярів: дис.. докт. наук 3 фіз. виховання і спорту 24.00.02. Дніпропетровськ. 2009. 454 с.

8. Москаленко Н. В. Фізичне виховання молодших школярів: [монографія] 3-є вид., перероб. та допов. Дніпропетровськ: Інновація. 2014. 372 с.

9. Москаленко Н.В., Єлісєєва Д.С. Самостійні заняття в процесі фізичного виховання дітей старшого шкільного віку. Спортивний вісник Придніпров’я. Дніпропетровськ. 2014. № 1. C. 81-86.

10. Москаленко Н., Альфьоров О. Організаційнометодичні аспекти сучасного уроку фізичної культури. Спортивний вісник Придніпров'я. Дніпропетровськ, ДДІФКіС. 2016. № 1. С. 196200.

11. Савченко В.А. Застосування інноваційних технологій у системі неперервної освіти вчителів фізичної культури Нової української школи. Науковий вісник Миколаївського національного університету імені В.О. Сухомлинського. № 3 (62). 2018. Т.2. Миколаїв : МНУ імені В.О. Сухомлинського. 2018. С. 288-292.

12. Савченко В.А. Сучасні підходи до навчання вчителів фізичної культури початкової школи в системі неперервної освіти. The 7-th International youth conference - Perspectives of science and education\| SLOVO $\backslash$ WORD. New York. USA. 2019. P. 55-66.

13. Савченко В.Г., Москаленко Н.В. Современные подходы к совершенстовавнию системы физического воспитания в общеобразовательных of students I-III groups health. Dissertation Physical Education and Sports Sciences 24.00.02. Lviv. 2014. 400 p. (in Ukrainian).

3. Bodnar I. R., Kindzera A. B. (2016). Leisure of Ukrainian students and place of motor activity in it. Pedagogy, psychology and medical and biological problems of physical education and sports. №5. P.11-18. Doi: 10.15561/18189171. 2016.0502. (in Ukrainian).

4. Demidova O.M. (2015). Physical training of dancers 15-16 years at the stage of specialized basic training. dissertation on the subject. Sciences. degree of Candidate of Science in Physical Education and Sports. 24.00.01. Dnipropetrovsk. DDIFKiS. 230 p. (in Ukrainian).

5. Foran A. (2010). Physical Activity and Heals Guidelines: Recommendations for Various Ages, Fitness Levels, and Conditions from 57 Authoritative Sources. Paperback. 368 p. (in English).

6. Innovative technologies in physical education of students. Moskalenko N.V., Vlasyuk O.O., Stepanova I.V., Shiyan O.V. (2011). Title of the book. "Innovation". Dnipropetrovsk. 235 p. (in Ukrainian).

7. Moskalenko N.V. (2009). Theoretical and methodological foundations of innovative technologies in the system of physical education of younger students: doctoral dissertation Physical Education and Sports Sciences 24.00.02. Dnipropetrovsk. 454 p. (in Ukrainian).

8. Moskalenko N.V. (2014). Physical education of younger students: [monograph] 3rd ed., revised. and extra. Dnepropetrovsk: Innovation. 372 p. (in Ukrainian).

9. Moskalenko N.V., Yelisieieva D. S. (2014) Independent classes in the process of physical education of older school children. Prydniprovsky Sports Newsletter. Dnipropetrovsk. № 1. P. 81-86. (in Ukrainian).

10. Moskalenko N., Alforov O. (2016). Organizational and methodical aspects of the modern lesson of physical culture. Prydniprovsky Sports Newsletter. Dnipropetrovsk, DDIFKiS. № 1. P. 196-200. (in Ukrainian).

11. Savchenko V. A. (2018) Application of innovative technologies in the system of continuous education of physical education teachers of the New Ukrainian School. Scientific Bulletin of Mykolaiv National University named after V.O. Sukhomlinsky.. T.2.P. 288-292. (in Ukrainian).

12. Savchenko V. A. (2019). Modern approaches to teaching elementary school physical education teachers in the system of continuous education. The 7-th International youth conference - Perspectives of science and education\| SLOVO $\backslash$ WORD. New York. USA. P. 55-66. (in USA). 
школах. Материалы XXII Международного научного Конгресса «Олимпийский спорт и спорт для всех». Тбилиси. 2018. С. 184-187.

14. Скалій О.В. Комп’ютерні технології диференціації процесу фізичного виховання школярів (на прикладі навчання плавання) : дис...канд. наук 3 фізичного виховання і спорту: 24.00.02. Тернопіль. 2002. 213 с.

15. Елисеева Д.С. Самостоятельные занятия по физическому воспитанию детей школьного возраста. Молодая спортивная наука Беларуси: материалы Междунар.науч.-практ. конф. Минск, 2014 г. Ч.1. С. 248-250.

16. Слісєєва Д.С. Інноваційна технологія зміцнення здоров'я дітей старшого шкільного віку в процесі самостійних занять фізичним вихованням : дис. на здобуття наукового ступеня канд. наук 3 фіз. виховання і спорту : 24.00.02. Дніпропетр. держ. ін-т фіз. культури і спорту. Дніпро. 2016. 237 c.

17. Захожий В.В. Методика формування готовності старшокласників до самостійних занять фізичними вправами: автореф. дис. на здобуття наук. ступеня канд. пед. наук: 13.00.02. Луцьк. 2011. $20 \mathrm{c}$.
13. Savchenko V. H., Moskalenko N. V. (2018). Modern approaches to the perfection of the physical education system in secondary schools. Materials of the XXII International Scientific Congress "Olympic Sports and Sports for All". Tbilisi. 2018. S. 184-187. (in Georgia).

14. Skaliy O.V. (2002). Computer technologies of differentiation of the process of physical education of schoolchildren (on the example of swimming instruction). Dissertation of Physical Education and Sports Sciences: 24.00.02. Ternopil. 213 p. (in Ukrainian).

15. Yelisieieva D. S. (2014). Independent classes in physical education of school children. Young sports science of Belarus: materials of the International scientific-practical. Minsk. Part.1. P. 248-250. (in Belarus)

16. Yelisieieva D. S. (2016). Innovative technology to promote the health of older children in the process of independent physical education. Dissertation of Physical Education and Sports Sciences: 24.00.02. Dnipro. 237 p. (in Ukrainian).

17. Zakhozhiy V.V. (2011). The technique of forming the readiness of high school students to take independent exercise. Abstract of dissertation work for the candidate of pedagogical sciences: 13.00.02. Lutsk. 20 p. (in Ukrainian).

\section{Москаленко Наталія}

Придніпровська державна академія фізичної культури і спорту м. Дніпро, вул. Набережна Перемоги, 10, 41000, Україна e-mail: moskalenkonatali2016@gmail.com

\section{Демидова Оксана}

Придніпровська державна академія фізичної культури і спорту м. Дніпро, вул. Набережна Перемоги, 10, 41000, Україна e-mail: grostiger@gmail.com

\section{Елисеева Дар'я}

Придніпровська державна академія фізичної культури і спорту м. Дніпро, вул. Набережна Перемоги, 10, 41000, Україна e-mail: yelisieieva.daria@gmail.com 